\title{
Dissolved organic carbon cycling in a subtropical seagrass-dominated lagoon
}

\author{
Susan Ziegler*, Ronald Benner \\ Marine Science Institute, University of Texas at Austin, 750 Channelview Drive, Port Aransas, Texas 78373, USA
}

\begin{abstract}
The cycling of dissolved organic matter (DOM) and its significance to ecosystem metabolism was studied over a 16 mo period in a Thalassia testudinum dominated meadow. The benthos was usually net autotrophic (annual gross primary production to respiration ratio $[P: R]=1.3$ ) while water column respiration $(R)$ exceeded gross primary production (annual $P: R=0.3$ ). Net fluxes of dissolved organic carbon (DOC) from the benthos primarily occurred in the light $\left(0\right.$ to $\left.18 \mathrm{mmol} \mathrm{C} \mathrm{m} \mathrm{m}^{-2}\right)$ and from seagrass-dominated areas, suggesting that release of DOC was mainly due to seagrass exudation. Net benthic DOC fluxes measured in the light were significantly correlated $(\mathrm{p}<0.0001, \mathrm{n}=61)$ with benthic net primary production (NPP). Average daily benthic NPP was significantly correlated to water column $\mathrm{R}(\mathrm{p}<0.002, \mathrm{n}=7$ ) and appeared to explain about $88 \%$ of the variability in daily water column R. Estimates of bacterioplankton growth efficiencies ranged from 21 to $38 \%$, with peaks corresponding to maximal benthic DOC fluxes in spring and summer. Bacterioplankton were responsible for the remineralization of most $(>50 \%)$ of the DOC released from the benthos on a daily basis. Annual estimates of bacterioplankton $\mathrm{C}$ demand, based on water column $\mathrm{R}\left(\sim 8 \mathrm{~mol} \mathrm{C} \mathrm{m} \mathrm{Cr}^{-2}\right)$, represented $>50 \%$ of the benthic NPP $\left(\sim 14 \mathrm{~mol} \mathrm{C} \mathrm{m}{ }^{-2} \mathrm{yr}^{-1}\right)$. These measurements indicate a stronger linkage between benthic and water column processes than previously believed, and it appears that water column heterotrophic processes are largely dependent upon seagrass exudation.
\end{abstract}

KEY WORDS: Seagrass $\cdot$ Carbon cycling $\cdot$ Exudation $\cdot$ DOC

\section{INTRODUCTION}

Seagrass systems are highly productive, maintaining rates of primary production similar to those of salt marsh and coral reef ecosystems (Odum et al. 1959, Odum 1971). Laguna Madre, Texas, USA, is a large $\left(\sim 1000 \mathrm{~km}^{2}\right)$ seagrass-dominated, shallow lagoon which receives little riverine input or precipitation (Trewartha 1961, Behrens 1966, Critchfield 1974). Despite the lack of riverine sources of nutrients this ecosystem is highly productive (Odum \& Wilson 1962, Ziegler \& Benner unpubl.) and has been an important source of fish, contributing as much as $50 \%$ of the total annual catch from the Texas coast (Hedgpeth 1967). Seagrass meadows cover approximately $75 \%$ of the

\footnotetext{
- Present address: Geophysical Laboratory, Carnegie Institution of Washington, 5251 Broad Branch Road N.W., Washington, DC 20015, USA.E-mail: ziegler@gl.ciw.edu
}

total area of Laguna Madre and are thought to be responsible for supporting the high secondary production of this system (Odum \& Wilson 1962, Quammen \& Onuf 1993, Dunton \& Tomasko 1994). Stable carbon isotopic signatures of many animals in Laguna Madre, including top carnivores such as redfish and seatrout, have indicated the importance of seagrass-derived $C$ in higher trophic levels (Fry \& Parker 1979).

Much is known about the distribution and physiology of seagrasses (den Hartog 1977, McRoy \& McMillan 1977), but the sources, transformations and fates of organic matter produced within these systems are not well understood. Direct grazing on living seagrass tissues has been found to be relatively minor, and this is attributed to the abundance of structural polysaccharides and phenolic compounds in seagrasses (Thayer et al. 1975, Morgan 1980, Mann 1988). The transfer of seagrass $C$ to secondary production is thought to occur primarily through detritus-based food webs (Robertson 
et al. 1982, Chin-Leo \& Benner 1991, Peduzzi \& Herndl 1991). Microorganisms, utilizing dissolved organic matter (DOM) released through macrophyte exudation, leaching and decomposition (Benner et al. 1986, Findlay et al. 1986), are considered a primary conduit in the transfer of this organic matter to higher trophic levels (Tenore 1977).

The release of DOM from submerged aquatic plants has been found to occur through exudation during photosynthesis (Hough \& Wetzel 1975, Brylinsky 1977). However most studies report that release of dissolved organic carbon (DOC) by seagrass leaves is less than $5 \%$ of the carbon fixed during photosynthesis (Brylinsky 1977, Penhale \& Smith 1977). Almost all estimates of seagrass exudation have been made using radiotracers in laboratory incubations. These measurements are considered minimal estimates of the release of DOC by submerged plants because of the necessity to assume isotopic equilibrium.

Several studies have demonstrated the transfer of DOM from seagrasses to the epiphytic assemblages associated with them (Hough \& Wetzel 1975, Penhale \& Thayer 1980, Kirchman et al. 1984), but very little information exists regarding the transfer of DOM from seagrasses to heterotrophic microorganisms in the water column. This is surprising considering bacterial production in the water column of seagrass beds is relatively high and has been found to vary diurnally, suggesting that bacterial activity is related to seagrass photosynthesis (Moriarty \& Pollard 1982, Chin-Leo \& Benner 1991). Diurnal variation in bacterioplankton production was found in Laguna Madre and only about 10 to $20 \%$ of this change could be attributed to changes in water temperature (Chin-Leo \& Benner 1991). Shifts in the quantity and quality of DOM, related to light-mediated processes such as seagrass or algal exudation, were proposed to be responsible for enhanced bacterial production during daylight hours (Chin-Leo \& Benner 1991).

Kirkman \& Reid (1979) reported a relatively high proportion of gross primary production (43\%) was released as DOC from living and decaying seagrass Ieaves. Decomposition and leaching are potentially important sources of DOM in seagrass systems. Very few studies have directly determined the significance of processes responsible for the production of DOM and its utilization relative to the metabolism of a seagrass community. In the present study, we investigated benthic and water column primary production, respiration, and DOC fluxes over a 16 mo period in a Thalassia testudinum meadow in Laguna Madre. The purpose of our study was to investigate (1) the sources of DOM, (2) the fate of DOM in the water column, and (3) its significance to the metabolism of this seagrass system.

\section{MATERIALS AND METHODS}

Site description. Laguna Madre is the southernmost estuary located on the Texas coast, and is separated from the Gulf of Mexico by Padre Island. It is divided into the upper and lower Laguna Madre by $40 \mathrm{~km}$ of sand and mud flats that are infrequently inundated. The Gulf Intracoastal Waterway, a dredged shipping channel, traverses the length of the system cutting through the tidal flats connecting the upper and lower portions of the system. The lagoon extends $200 \mathrm{~km}$ south from Corpus Christi Bay to the Rio Grande, is about $12 \mathrm{~km}$ wide at its widest point, and has an average natural depth of about $1 \mathrm{~m}$. There is very little freshwater input into this system. Annual precipitation in the region ranges from 61 to $79 \mathrm{~cm}$ and total freshwater discharge is about $10 \mathrm{~m}^{3} \mathrm{~s}^{-1}$ in most years (Trewartha 1961, Behrens 1966, Critchfield 1974, TDWR 1983, NOAA 1990).

Our study was performed in a Thalassia testudinum dominated seagrass meadow in the southern portion of the lower Laguna Madre. This seagrass population has very few epiphytes associated with it. Beds of Syringodium filiforme Kutzing and Halodule wrightii as well as drift algal species such as Digenia simplex and Laurencia poitei also occur in the lower Laguna Madre (Humm \& Hildebrand 1962, Onuf 1996). The study site was located east of the Gulf Intracoastal Waterway, about $10 \mathrm{~km}$ north of the Brazos Santiago Pass and about $2 \mathrm{~km}$ west of Padre Island (for map see Herzka \& Dunton 1996). A total of ten $5 \mathrm{~d}$ trips were made to the lower Laguna Madre approximately every 6 to 8 wk from February 1996 to June 1997.

Water column temperature, salinity, and depth were measured every $10 \mathrm{~min}$ and recorded using a data logging system (YSI6000, YSI Inc.) which was secured at mid-depth $(\sim 0.5 \mathrm{~m})$ for the duration of each trip. Salinity was determined by measuring specific conductivity with a probe calibrated prior to each deployment using $\mathrm{KCl}$ standards. Depth was measured using a strain gauge sensor and was checked at least once during each deployment. The height of the gauge from the bottom was added to the measurements to calculate total water column depth.

Sample collection and treatment. Samples for DOC analysis, except those collected in March 1997, were unfiltered. All samples collected in March 1997 were filtered through muffled GF/F filters $\left(450^{\circ} \mathrm{C}\right.$ for $\left.2 \mathrm{~h}\right)$. Comparisons of filtered versus unfiltered samples collected at our site in November 1996 and June 1997 indicated that particulate organic carbon represented a small fraction ( 1 to $6 \%$ ) of total organic carbon. However, in January a 'brown tide' phytoplankton bloom contributed about $20 \%$ of the total organic carbon measured. DOC concentrations determined for sam- 
ples collected in January 1997 were also estimated from total organic carbon concentrations corrected for the average difference between 6 filtered and 6 unfiltered samples collected from the site during that trip.

Average daily DOC concentrations were determined from samples collected in $45 \mathrm{ml}$ glass bulbs (muffled) at 60 or $70 \mathrm{~min}$ intervals over a $24 \mathrm{~h}$ period from about $0.6 \mathrm{~m}$ depth using a custom built autosampler. Sample bulbs were kept in the dark. Ten ml samples were transferred from the bulbs into muffled $20 \mathrm{ml}$ glass vials, acidified with $100 \mu 120 \%$ HPLC-grade $\mathrm{H}_{3} \mathrm{PO}_{4}$, sealed with Teflon lined caps, and stored upright on ice until brought back to the laboratory where samples were refrigerated. DOC was determined by high-temperature oxidation using a Shimadzu TOC-5000 analyzer (Benner \& Strom 1993).

Samples collected for dissolved inorganic carbon (DIC) analysis were transferred, in duplicate, into $3.7 \mathrm{ml}$ glass vials, fixed with $10 \mu \mathrm{l}$ of $50 \mathrm{mM} \mathrm{HgCl}_{2}$, and tightly capped without headspace. DIC was determined using a Shimadzu TOC 5000 analyzer with standards of sodium bicarbonate and sodium carbonate.

Light measurements. Photosynthetically active radiation (PAR) measurements were collected at our site using an IL 1700 radiometer (International Light Inc., Newburyport, MA, USA) with a flat broadband submersible detector (constant spectral response for 400 to $700 \mathrm{~nm}$; SUL033; International Light Inc.). Measurements were made at $10 \mathrm{~cm}$ intervals from the surface to the bottom of the water column 2 to 5 times throughout at least $1 \mathrm{~d}$ on each trip. Attenuation coefficients $(k)$ were determined from the slope of the least-squares linear fit of depth versus the natural log of the PAR irradiance measured close to solar noon. At a site close to ours and in the same meadow, underwater PAR irradiance was monitored continuously using a Ll-193SA spherical quantum sensor in conjunction with a LI1000 datalogger (LI-COR Inc., Lincoln, NB, USA) (K. Dunton unpubl. data). The irradiance ( $\mu$ mol $\mathrm{m}^{-2} \mathrm{~s}^{-1}$ ) was measured at 1 min intervals underwater at the seagrass canopy level and was integrated hourly and logged. These data were summed over a $24 \mathrm{~h}$ period to calculate daily irradiance $\left(\mathrm{E} \mathrm{m}^{-2} \mathrm{~d}^{-1}\right)$. PAR irradiance obtained with the IL1700 at our site was, on average, $16 \%$ lower than measurements made with the LI-COR spherical sensor at the adjacent site, and trends in data between the 2 instruments were similar.

Benthic GPP and R. Benthic gross primary production (GPP) and respiration (R) were determined by measuring changes in DIC concentrations in light and dark chambers. Chambers were constructed from 201 Nalgene polycarbonate carboys by removing the bottoms and adding a sampling port at the shoulder. Caps of the chambers were fitted with a current-driven stirring mechanism to mimic in situ water movement (see
Ziegler \& Benner 1998). Covers for the chambers were constructed of dark gray plastic and used for the dark incubations. Four chambers were placed carefully about $8 \mathrm{~cm}$ into the sediment at 3 seagrass-dominated sites (primarily Thalassia testudinum) and 1 unvegetated area (void of all macrophytes) adjacent to the other chambers. An average of the 4 chambers was used to estimate benthic metabolism in the lower Laguna Madre. The distribution of chambers was based on estimates of the areal coverage of seagrassdominated $(75 \%)$ and unvegetated $(25 \%)$ sediments in the the lower Laguna Madre (Quammen \& Onuf 1993).

To minimize the effects of disturbance to the sediments on metabolism measurements, benthic chambers were deployed without caps in the late afternoon prior to the day benthic measurements were made. At dawn, water in the chambers was exchanged with overlying water using a hand-held pump. Dark incubations were conducted early in the morning and late in the afternoon to avoid dramatic shifts in light levels. Incubations lasted for 1.5 to $4 \mathrm{~h}$ depending upon level of activity (i.e. incubations were the longest in winter and shortest in summer). Samples for DIC were collected through the sampling port using a $60 \mathrm{ml}$ syringe. After completion of all benthic incubations, volumes for all 4 chambers were determined by injecting each with $15 \mathrm{ml}$ of $30 \mathrm{mM} \mathrm{NaNO}_{3}$. Each chamber was stirred for 2 min before a sample was collected and later frozen. The concentration of $\mathrm{NO}_{3}{ }^{-}$in these samples, usually about 20 to $24 \mu \mathrm{M}$ after the addition, was used to estimate the volume of each chamber during every trip. Error in the estimate of the chamber volumes was dependent upon the measurement of $\mathrm{NO}_{3}{ }^{-}$, which was determined with a precision of $4 \%$ at $1 \mu \mathrm{M}$ (Ziegler \& Benner unpubl.). The daily rates of net primary production (NPP) for all incubations were based on the number of daylight hours. The number of hours of light for each day was based on the beginning and end of saturating PAR light levels for seagrasses $\left(\sim 300 \mu \mathrm{E} \mathrm{m}^{-2} \mathrm{~s}^{-1}\right.$; Herzka \& Dunton 1997). The daily rates of $R$ for all incubations were calculated for the entire $24 \mathrm{~h}$ period. GPP was estimated for each chamber by adding the average DIC production measured in the dark to the corresponding average DIC consumption measured in the light. Benthic GPP and $R$ rates were corrected for water column GPP and $R$ measured as described below.

Water column GPP and R. Water was collected around dawn and incubated in light and dark bottles for about $12 \mathrm{~h}$ during the day to estimate daytime NPP and $\mathrm{R}$ in the water column. Another water sample was collected around sunset and incubated overnight in dark bottles to estimate nighttime respiration for each trip except June 1996. Water samples were dispensed into clean (acid washed and rinsed) $300 \mathrm{ml}$ biological 
oxygen demand bottles or $90 \mathrm{ml}$ quartz bottles. Dark bottles were wrapped in aluminum foil and all bottles were incubated in situ on racks set at mid-depth $(\sim 0.5 \mathrm{~m})$ in the water column. Changes in dissolved oxygen were determined by Winkler titration using an automated titrator with potentiometric endpoint detection (Biddanda et al. 1994). Rates of net $\mathrm{O}_{2}$ production or consumption were determined from the slope of the least-squares linear regression analysis $(n \geq 6)$ of the dissolved oxygen data versus time. Consumption of dissolved oxygen in dark incubations during the daytime were added to the value for light samples to obtain estimates of GPP. Water column GPP and R rates based on $\mathrm{O}_{2}$ were converted to units of carbon using photosynthesis and respiration quotients of 1.2 and 1.0, respectively (Oviatt et al. 1986).

Bacterial abundance and production. Samples for bacterial abundance were collected in the morning during $1 \mathrm{~d}$ of each trip. Triplicate $5 \mathrm{ml}$ samples were collected into clean glass vials and fixed with $250 \mu \mathrm{l}$ of $0.2 \mu \mathrm{m}$ filtered formaldehyde to obtain a $2 \%$ final concentration. Subsequently, samples were stored at about $4^{\circ} \mathrm{C}$ for no more than 1 mo before bacterial abundances were determined by epifluorescence microscopy of DAPI-stained samples collected on $0.2 \mu \mathrm{m}$ black Nucleopore filters (Porter \& Feig 1980).

Bacterial production was estimated from rates of protein synthesis using ${ }^{3} \mathrm{H}$-leucine (Kirchman et al. 1985). Triplicate $20 \mathrm{ml}$ samples were incubated with a 20 nM final concentration of ${ }^{3} \mathrm{H}$ leucine (specific activity $50 \mathrm{Ci} \mathrm{mmol}{ }^{-1}$, New England Nuclear) for $1 \mathrm{~h}$ in ground glass stoppered test tubes in the dark in a circulating bath of Laguna Madre water. One formaldehyde ( $4 \%$ final concentration) killed control was run with triplicate live samples to determine abiotic sorption of the labeled leucine. Incubations were terminated by filtration through $0.2 \mu \mathrm{m}$ pore size MF Nucleopore membrane filters. Filters were immediately extracted with ice cold 5\% trichloroacetic acid for $5 \mathrm{~min}$, followed by a $5 \mathrm{ml}$ rinse with ice cold $5 \%$ trichloroacetic acid. The filters were stored in scintillation vials and refrigerated until measurement of radioactivity within $7 \mathrm{~d}$ of collection. Prior to scintillation counting samples were extracted at $50^{\circ} \mathrm{C}$ for $1 \mathrm{~h}$ using the tissue solubilizer Solvable (Dupont, New England Nuclear Inc.) as described by Amon $\&$ Benner (1998). Rates of bacterial carbon production were estimated from leucine incorporation rates using conversion factors of $4.3 \times 10^{16}$ cells $\mathrm{mol}^{-1}$, derived from experiments using Laguna Madre water (Chin-Leo \& Benner 1991), and $20 \mathrm{fg} \mathrm{C} \mathrm{Cell}^{-1}$ (Lee \& Fuhrman 1987).

Bacterial growth efficiencies were calculated as the ratio of bacterial production to bacterial production plus water column $\mathrm{R}$, except in January and March 1997. During January and March 1997 primary production was relatively high due to the presence of the brown tide. Respiration due to bacterioplankton, at this time, was assumed to be $70 \%$ of the plankton $\mathrm{R}$. This assumption was based on previous measurements of bacterial $\mathrm{R}$ ranging from 40 to $100 \%$ of plankton $\mathrm{R}$ for different marine environments (Williams 1981, ChinLeo \& Benner 1992, Biddanda et al. 1994).

Benthic DOC fluxes. Net fluxes of DOC to and from the benthos were measured at the same time as DIC fluxes for benthic GPP and R. DOC samples were collected from the chambers, stored and analyzed as described above. Net benthic DOC fluxes were corrected for the production (exudation by phytoplankton assumed to be $10 \%$ of GPP; Lancelot 1984, Williams 1990, Strom et al. 1997) and consumption (water column R) of DOC in the water contained in each chamber. The net DOC fluxes that occurred in the light and dark were calculated and reported separately as daily rates, based on the number of hours of saturating light. Daily net DOC fluxes were calculated as the sum of net DOC flux in the light plus the net DOC flux in the dark.

Table 1 Water column parameters in the lower Laguna Madre from June 1996 through June 1997

\begin{tabular}{|c|c|c|c|c|c|}
\hline $\begin{array}{l}\text { Date } \\
(\mathrm{mo} / \mathrm{d} / \mathrm{yr})\end{array}$ & $\begin{array}{l}\text { Avg. water } \\
\text { temp. }\left({ }^{\circ} \mathrm{C}\right)\end{array}$ & $\begin{array}{l}\text { Water depth } \\
\text { range }(\mathrm{cm})\end{array}$ & $\begin{array}{l}\text { Daily PAR } \\
\left(E \mathrm{~m}^{-2} \mathrm{~d}^{-1}\right)\end{array}$ & $\begin{array}{l}\mathrm{PAR} k^{\mathrm{b}} \\
\left(\mathrm{m}^{-1}\right)\end{array}$ & $\begin{array}{c}\text { Average } \\
\text { DOC }(\mu \mathrm{M})\end{array}$ \\
\hline $6 / 12 / 96$ & 29.5 & $88-120$ & 42.4 & & \\
\hline $6 / 13 / 96$ & 30.5 & $94-126$ & 41.6 & & 190 \\
\hline $6 / 14 / 96$ & 30.6 & $95-124$ & 39.7 & 0.64 & \\
\hline $7 / 23 / 96$ & 30.7 & $93-11.3$ & 41.4 & & \\
\hline $7 / 24 / 96$ & 30.7 & $87-113$ & 38.5 & & 175 \\
\hline $7 / 25 / 96$ & 30.6 & $82-114$ & 39.3 & 0.85 & \\
\hline $9 / 10 / 96$ & 30.4 & $99-117$ & 30.2 & & 202 \\
\hline $9 / 11 / 96$ & 30.6 & $97-116$ & 35.9 & 0.70 & \\
\hline $9 / 12 / 96$ & 30.6 & $101-116$ & 33.0 & & \\
\hline $11 / 5 / 96$ & 22.7 & $123-139$ & 18.4 & 0.66 & 167 \\
\hline $11 / 6 / 96$ & 25.1 & $121-130$ & 10.8 & & \\
\hline $1 / 20 / 97$ & 10.9 & $74-113$ & 6.9 & 1.10 & 414 \\
\hline $1 / 21 / 97$ & 12.2 & $72-100$ & 20.5 & & \\
\hline $3 / 7 / 97$ & 19.1 & $102-123$ & 21.4 & & 234 \\
\hline $3 / 8 / 97$ & 20.8 & $103-128$ & 17.1 & 0.86 & \\
\hline $3 / 9 / 97$ & 22.1 & $102-127$ & & 0.91 & \\
\hline $6 / 23 / 97$ & 26.2 & $102-129$ & 9.2 & & \\
\hline $6 / 24 / 97$ & 26.7 & $94-128$ & 14.4 & & 142 \\
\hline $6 / 25 / 97$ & 29.0 & $93-120$ & 34.1 & 0.80 & \\
\hline \multicolumn{6}{|c|}{$\begin{array}{l}\text { ¿From continuous PAR measurements made above seagrass canopy } \\
(\sim 20 \mathrm{~cm} \text { from bottom) (K. Dunton unpubl.) } \\
\text { bAttenuation coefficient }\end{array}$} \\
\hline
\end{tabular}


Annual estimates. The annual weighted average for water column GPP was calculated by applying the daily rates measured in a particular month to either the previous or the following month. These daily rates were multiplied by the number of days in the 2 mo period and annual rates were summed over the entire year from the bimonthly estimates. The annual estimate of benthic GPP was calculated from the linear regression of daily benthic GPP estimates versus the corresponding daily PAR flux $\left(\mathrm{n}=7, \mathrm{r}^{2}=0.88, \mathrm{p}=\right.$ 0.002 ) by applying this relationship to continuous PAR data collected from June 1996 through June 1997. The annual estimate of benthic GPP for the unvegetated sediments was also calculated from the linear regression of daily benthic GPP in these sediments versus the corresponding daily PAR flux ( $\mathrm{n}=7, \mathrm{r}^{2}=0.95, \mathrm{p}=$ 0.001 ), and applying this relationship to the continuous PAR data. The annual estimate of benthic $R$ was calculated from the estimates of benthic $R$ versus average daily water temperature $\left(n=7, r^{2}=0.85, p=0.003\right)$ by applying this relationship to continuous water temperature data collected from June 1996 through June 1997. The annual estimate of NPP was calculated from the difference in the annual estimates of GPP and R. Water column $R$ was estimated for the year using the linear regression of water column $R$ versus benthic NPP ( $\left.n=7, r^{2}=0.88, p=0.002\right)$, and benthic NPP was calculated from each daily estimate of benthic GPP and $\mathrm{R}$ based on daily PAR and water temperature, respectively.

\section{RESULTS}

Average daily water temperature ranged from 10.9 to $30.7^{\circ} \mathrm{C}$ (Table 1 ). Water depth was lowest in January ( 72 to $113 \mathrm{~cm}$ ), which was also when the greatest range in depth occurred. Water depth was greatest in November 1996 when the average daily depths ranged from 1.21 to $1.39 \mathrm{~m}$. The attenuation coefficient for PAR was highest in January 1997 corresponding with a brown tide bloom. Average DOC concentrations were $\leq 202 \mu \mathrm{M}$, except during January and March 1997 when phytoplankton production was high (Table 1). Diel variations in DOC concentrations were only found in June and July 1996 when DOC concentrations increased as much as 50 and $25 \mu \mathrm{M}$ during the day, respectively.

\section{Benthic primary production and respiration}

Benthic (average of 4 chambers) GPP ranged from 45 to $233 \mathrm{mmol} \mathrm{C} \mathrm{m} \mathrm{m}^{-2} \mathrm{~d}^{-1}$ (Table 2, Fig. 1) and was significantly correlated to daily PAR fluxes $\left(r^{2}=0.89, p<0.01\right.$,
Table 2. Average gross primary production (GPP), respiration $(R)$, net primary production (NPP) (all in mmol $\mathrm{C} \mathrm{m}^{-2} \mathrm{~d}^{-1}$ ), and $P: R$ ratio \pm 1 standard deviation for the benthos and water column

\begin{tabular}{|lcccc|}
\hline Month & GPP & $\mathrm{R}$ & $\mathrm{NPP}$ & $\mathrm{P}: \mathrm{R}$ \\
\hline Benthos & & & & \\
Jun & $191 \pm 99$ & $154 \pm 108$ & $37 \pm 15$ & $1.24 \pm 0.7$ \\
Jul & $233 \pm 109$ & $182 \pm 119$ & $52 \pm 43$ & $1.28 \pm 1.0$ \\
Sep & $212 \pm 67$ & $208 \pm 80$ & $4 \pm 19$ & $1.02 \pm 5.0$ \\
Nov & $123 \pm 60$ & $123 \pm 54$ & $1 \pm 9$ & $1.00 \pm 15.6$ \\
Jan & $45 \pm 15$ & $43 \pm 26$ & $4 \pm 9$ & $1.04 \pm 2.1$ \\
Mar & $93 \pm 40$ & $62 \pm 38$ & $31 \pm 18$ & $1.50 \pm 1.0$ \\
Jun & $141 \pm 72$ & $135 \pm 92$ & $6 \pm 31$ & $1.04 \pm 0.9$ \\
& & & Average P:R & $1.16 \pm 0.2$ \\
Water column & & & \\
Jun & $3.0 \pm 1.6$ & $27.0 \pm 5.9$ & $-23.9 \pm 2.8$ & $0.11 \pm 0.5$ \\
Jul & $0.4 \pm 3.5$ & $25.5 \pm 5.9$ & $-25.1 \pm 6.8$ & $0.01 \pm 9.1$ \\
Sep & $2.5 \pm 1.1$ & $9.4 \pm 0.9$ & $-6.9 \pm 1.4$ & $0.27 \pm 0.5$ \\
Nov & $1.0 \pm 0.7$ & $6.6 \pm 1.8$ & $-5.6 \pm 2.0$ & $0.15 \pm 0.8$ \\
Jan & $35.5 \pm 5.4$ & $10.7 \pm 4.7$ & $24.8 \pm 7.1$ & $3.32 \pm 0.5$ \\
Mar & $9.2 \pm 3.0$ & $17.0 \pm 6.5$ & $-7.8 \pm 7.2$ & $0.54 \pm 0.5$ \\
Jun & $5.7 \pm 2.3$ & $14.9 \pm 3.3$ & $-9.2 \pm 4.1$ & $0.38 \pm 0.5$ \\
& & & Average P:R & $0.68 \pm 1.2$ \\
& & &
\end{tabular}
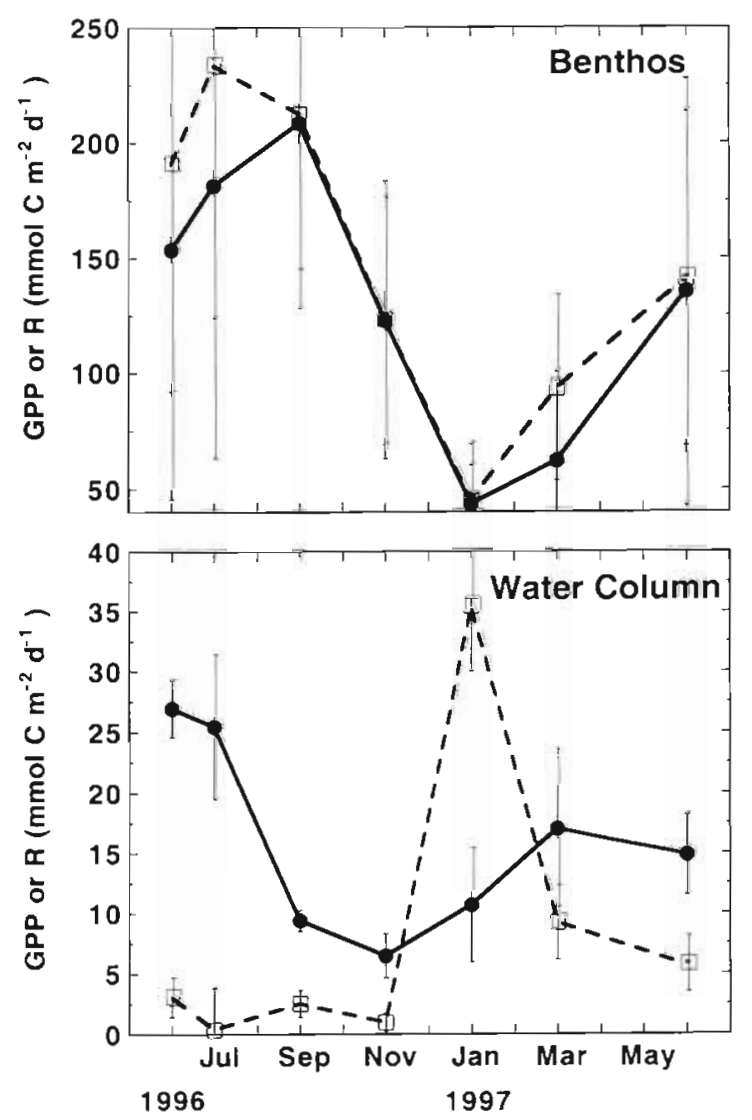

Fig. 1. Gross primary production (GPP) (- - - - ) and respiration (R) (-) for the benthos and the water column. Values represent means \pm 1 standard deviation 


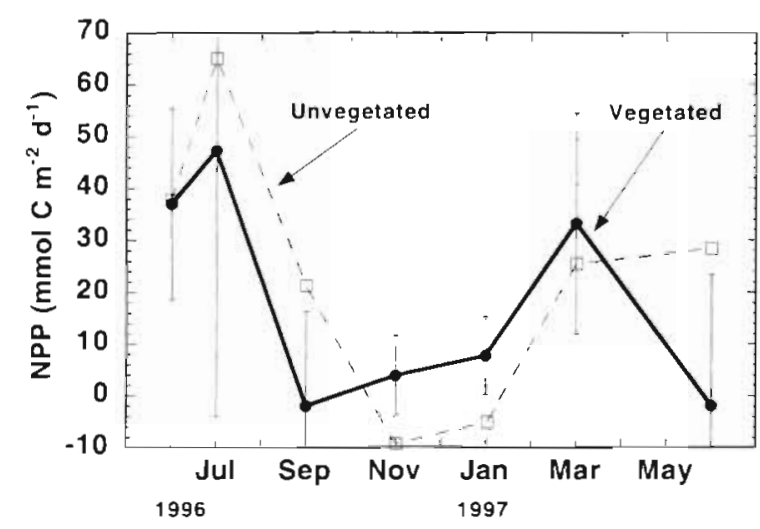

Fig. 2. Net primary production. (NPP) for the vegetated $(\longrightarrow-)$ and the unvegetated $(--\square--)$ sediments. Values for the vegetated sediments represent mean \pm 1 standard devia tion and the values for the unvegetated sediments represent the daily NPP for 1 chamber

$n=7$ ). GPP peaked in July and September and was lowest in January (Fig. 1). Benthic NPP ranged from 1 to $52 \mathrm{mmol} \mathrm{C} \mathrm{m} \mathrm{Cd}^{-1}$ and was not strongly correlated to daily PAR $\left(\mathrm{r}^{2}=0.49, \mathrm{p}=0.082, \mathrm{n}=7\right)$. Benthic $\mathrm{R}$ ranged from 43 to $208 \mathrm{mmol} \mathrm{C} \mathrm{m}^{-2} \mathrm{~d}^{-1}$ and was significantly correlated to average water temperature $\left(\mathrm{r}^{2}=0.85, \mathrm{p}<\right.$ $0.01, n=7$ ). The ratios of $P: R$ for the benthos were typically $>1$ and ranged from 1.0 to 1.5 (Table 2 ). The benthos was net autotrophic $(P: R=1.2 \pm 0.2)$ during the spring and summer whereas benthic GPP was nearly equivalent to $\mathrm{R}$ during fall and winter (Table 2, Fig. 1).

Unvegetated sediments were devoid of seagrasses, but benthic microalgae were present and relatively productive. The GPP of the unvegetated sediments was about half ( 30 to $112 \mathrm{mmol} \mathrm{C} \mathrm{m}^{-2} \mathrm{~d}^{-1}$ ) that of seagrass-dominated areas ( 47 to $287 \mathrm{mmol} \mathrm{C} \mathrm{m}^{-2} \mathrm{~d}^{-1}$ ). The NPP of the unvegetated sediments ranged from -9 to $65 \mathrm{mmol} \mathrm{C} \mathrm{m} \mathrm{Cd}^{-1}$, with an average of $23 \mathrm{mmol} \mathrm{C} \mathrm{m} \mathrm{m}^{-2}$ $\mathrm{d}^{-1}$. On average, the NPP of the vegetated and unvegetated sediments were fairly similar, and occasionally NPP was higher in the unvegetated sediments (Fig 2). The $P: R$ ratios for unvegetated sediments ( $P: R$ ranged from 0.78 to 6.26 , with an average of 3.36 ) were often much higher than those for seagrass-dominated sediments ( $P: R$ ranged from 0.99 to 1.43 , with an average of 1.13).

\section{Water column primary production and respiration}

Water column GPP was low and ranged from 0.4 to $9.2 \mathrm{mmol} \mathrm{C} \mathrm{m}^{-2} \mathrm{~d}^{-1}$ for all trips except January when it was $35.5 \mathrm{mmol} \mathrm{C} \mathrm{m} \mathrm{m}^{-2} \mathrm{~d}^{-1}$ because of a brown tide bloom (Table 2). Water column $\mathrm{R}$ was often much higher than GPP and ranged from 6.6 to $27.0 \mathrm{mmol} C$ $\mathrm{m}^{-2} \mathrm{~d}^{-1}$ Consequently, the P:R values for the water col- umn were low and ranged from 0.01 to 0.54 , indicating that the water column was net heterotrophic all year except for January when P:R = 3.32 (Table 2, Fig. 1). Because of the low rates of primary production in the water column almost all of the rates of NPP reported are negative values, indicating a 'deficit' of carbon produced in the water column (Table 2).

\section{Bacterial abundance and production}

The abundance of bacterioplankton ranged from 0.9 to $2.7 \times 10^{6}$ cells $\mathrm{ml}^{-1}$ and did not vary seasonally. Maximal abundances occurred in January during the brown tide bloom and minimal abundances occurred in September. Bacterial production in the water column at our site ranged from 1.8 to $9.1 \mathrm{mmol} \mathrm{C} \mathrm{m}^{-2} \mathrm{~d}^{-1}$ and was similar to bacterial production rates measured in the water column over other subtropical seagrass meadows, including the upper Laguna Madre (Moriarty \& Pollard 1982, Moriarty et al. 1990, Chin-Leo \& Benner 1991). Maximal rates of bacterioplankton production occurred in March, and the lowest rates were measured in November, corresponding with the high and low benthic $P: R$ ratios, respectively. The estimated bacterial growth efficiencies ranged from 21 to $38 \%$ (average $=29 \%$ ) and fell within range of most aquatic systems (del Giorgio et al. 1997). Maximal growth efficiencies occurred in September $(38 \%)$ and minimal efficiencies occurred in November $(21 \%)$.

\section{Benthic DOC fluxes}

Benthic DOC fluxes were greatest in the light, rang-

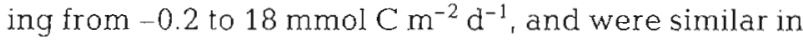
magnitude to DOC fluxes from seagrass blades in a Posidonia a ustralis dominated system (Kirkman \& Reid 1979) (Table 3, Fig 3). In the absence of light, DOC fluxes were typically negative (indicating benthic consumption of DOC) and ranged from -10.3 to $4 \mathrm{mmol} C$ $\mathrm{m}^{2} \mathrm{~d}^{-1}$ (Table 3, Fig. 3). The highest rates of benthic DOC release in the light occurred in July and September and the lowest rates were in November. The standard deviation of the means reported for the net benthic DOC fluxes are primarily due to the large difference between the seagrass-dominated and unvegetated sediments (Table 3, Fig. 3)

There typically were large differences in the net DOC fluxes measured in the seagrass-dominated incubations compared with those in incubations void of seagrasses. Net DOC fluxes in light incubations

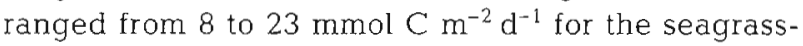

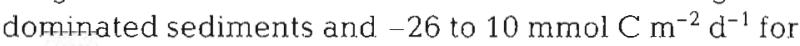
the unvegetated sediments (Table 3, Fig. 3b,c). Ben- 

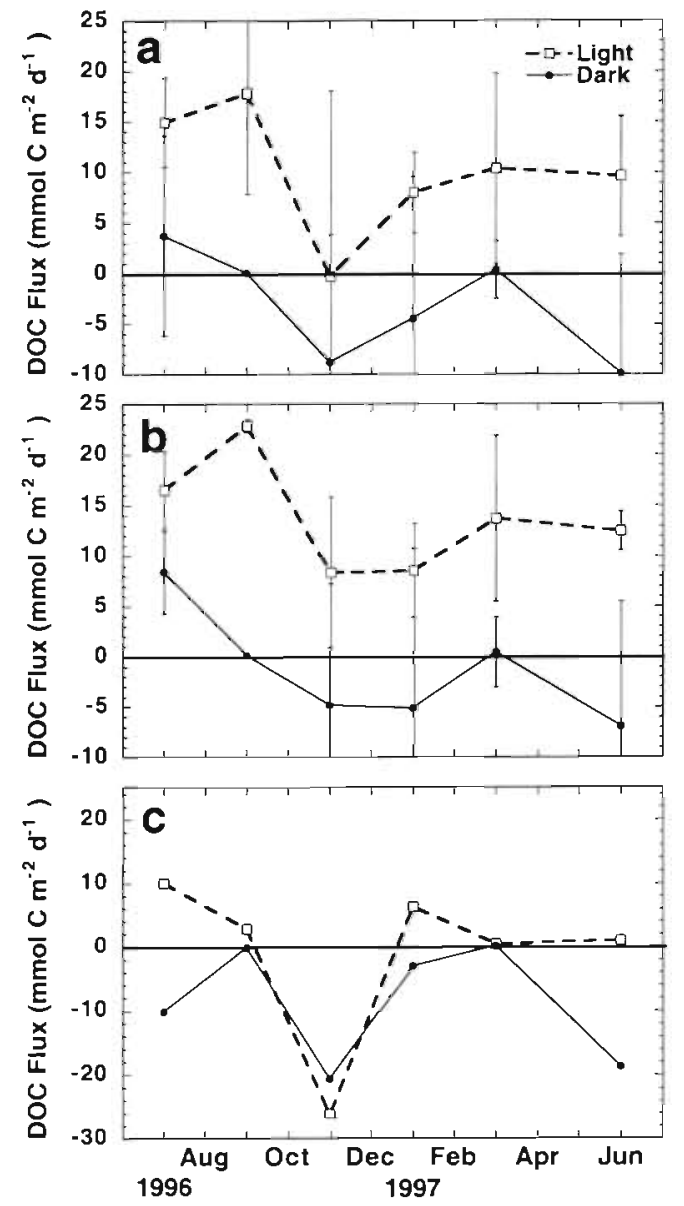

Fig. 3. Benthic dissolved organic carbon (DOC) fluxes measured in the light $(--\square--)$ and the dark $(\rightarrow-)$ for (a) the average of 4 incubations which included 3 in vegetated sediments and 1 in unvegetated sediments, (b) the average of the 3 vegetated sediment incubations, and (c) the unvegetated sediment incubations. All values represent the mean \pm 1 standard deviation with the exception of $(\mathrm{c})$ where values are taken from incubations of 1 chamber

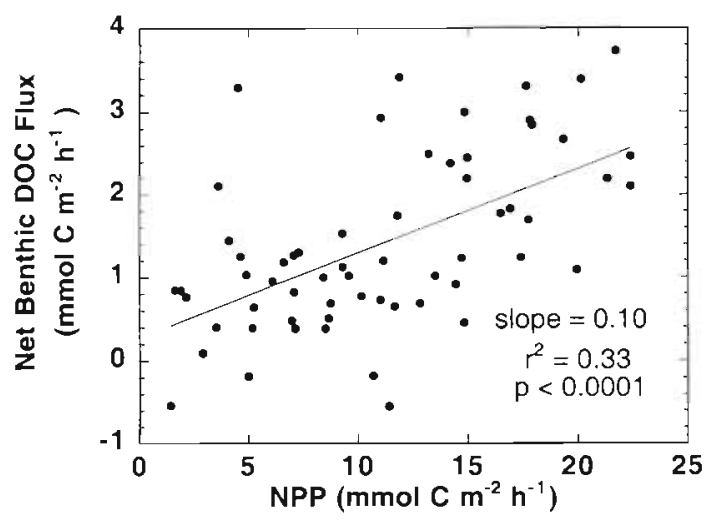

Fig. 4. Individual measurements $(n=61)$ of the net benthic DOC flux measured in the light versus the corresponding benthic net primary production (NPP)
Table 3. Net benthic DOC fluxes $\left(\mathrm{mmol} \mathrm{C} \mathrm{m}{ }^{-2} \mathrm{~d}^{-1}\right.$; average \pm 1 standard deviation) for daytime, nighttime, and $24 \mathrm{~h}$ periods. Negative values indicate benthic consumption of DOC

\begin{tabular}{|c|c|c|c|}
\hline Month & $\begin{array}{c}\text { Average net } \\
\text { benthic DOC } \\
\text { flux in light }\end{array}$ & $\begin{array}{l}\text { Average net } \\
\text { benthic DOC } \\
\text { flux in dark }\end{array}$ & $\begin{array}{l}\text { Net daily } \\
\text { DOC flux }\end{array}$ \\
\hline \multicolumn{4}{|l|}{ Benthos } \\
\hline Jul & $15.0 \pm 4.4$ & $3.8 \pm 9.9$ & $18.8 \pm 14.3$ \\
\hline Sep & $17.9 \pm 10.0$ & $0.1 \pm 0.1$ & $18.0 \pm 10.1$ \\
\hline Nov & $-0.2 \pm 18.3$ & $-8.8 \pm 12.7$ & $-9.0 \pm 31.0$ \\
\hline Jan & $8.0 \pm 3.9$ & $-4.4 \pm 14.0$ & $3.6 \pm 17.9$ \\
\hline Mar & $10.4 \pm 9.4$ & $0.4 \pm 2.8$ & $10.8 \pm 12.2$ \\
\hline Jun & $10.2 \pm 6.5$ & $-10.3 \pm 12.1$ & $-0.1 \pm 18.6$ \\
\hline \multicolumn{4}{|c|}{ Seagrass } \\
\hline Jul & $16.5 \pm 3.8$ & $8.4 \pm 4.1$ & $24.9 \pm 7.9$ \\
\hline Sep & $22.9 \pm 0.6$ & $0.1 \pm 0.1$ & $23.0 \pm 0.7$ \\
\hline Nov & $8.4 \pm 7.5$ & $-4.8 \pm 12.1$ & $3.6 \pm 19.6$ \\
\hline $\operatorname{Jan}$ & $8.6 \pm 4.7$ & $-5.1 \pm 15.8$ & $3.5 \pm 20.5$ \\
\hline Mar & $13.7 \pm 8.2$ & $0.5 \pm 3.5$ & $14.2 \pm 11.7$ \\
\hline Jun & $13.3 \pm 2.6$ & $-7.7 \pm 13.5$ & $5.6 \pm 16.1$ \\
\hline \multicolumn{4}{|c|}{ Unvegetated } \\
\hline Jul & 10.2 & -10.2 & 0.0 \\
\hline Sep & 2.9 & -0.1 & 2.8 \\
\hline Nov & -26.1 & -20.6 & -46.7 \\
\hline Jan & 6.4 & -3.0 & 3.4 \\
\hline Mar & 0.5 & 0.2 & 0.7 \\
\hline Jun & 1.0 & -18.0 & -17.0 \\
\hline
\end{tabular}

thic consumption of water column DOC was often observed in incubations over unvegetated sediments, particularly in November. Differences in the net DOC fluxes measured in the light between the 2 different benthic communities were small in July. However, in September, those that occurred in the seagrass-dominated areas were much larger. There was little seasonal trend in the net DOC fluxes measured over the unvegetated sediments, but net DOC fluxes varied seasonally over the seagrass-dominated sediments (Fig. 3b,c). The net DOC fluxes in both light and dark incubations decreased in the fall and winter and increased slightly in the spring.

There was a significant correlation between DOC fluxes from the benthos during light incubations and the corresponding NPP rates (Fig. 4). This regression analysis indicated that about $33 \%$ of the variability in the net benthic DOC fluxes measured in the light could be explained by benthic NPP. Benthic DOC fluxes represented about $10 \%$ of NPP (Fig. 4). There was also a weak but significant correlation between net benthic DOC fluxes in the light and average water temperature $\left(r^{2}=0.10, p<0.02, n=61\right)$. This regression analysis indicated that only about $10 \%$ of the variability in the net benthic DOC fluxes measured in the light could be explained by changes in water temperature. 


\section{DISCUSSION}

\section{Benthic primary production and respiration}

Benthic GPP rates measured in the lower Laguna Madre were within the range of measurements from other temperate, subtropical, and tropical seagrass systems (Odum \& Hoskin 1958, McRoy \& Helfferich 1974, Lindeboom \& DeBree 1982, Murray \& Wetzel 1987, Pollard \& Moriarty 1991). Benthic R was similar to the few measurements made in other temperate and subtropical seagrass systems (Odum \& Hoskin 1958, Murray \& Wetzel 1987). The benthos was net autotrophic but the annual P:R ratios were generally lower ( $P: R=$ 1.3) than those measured by Murray \& Wetzel (1987) for Zostera marina ( $\mathrm{P}: \mathrm{R}=2.1$ ) and Ruppia maritima ( $\mathrm{P}: \mathrm{R}$ $=1.4$ ) seagrass communities. However, Murray \& Wetzel (1987) made measurements during clear days in order to obtain maximum light levels for each season and potentially maximum $P: R$ values.

Although seagrasses are often the dominant primary producer in shallow systems, some investigators have found benthic microalgae to be important contributors to system primary production (Pomeroy 1959, Moncreiff et al. 1992). The NPP of the unvegetated and the vegetated sediments were generally similar in Laguna Madre, and both were similar to the NPP reported for unvegetated sediments in temperate Zostera marina and Ruppia maritima meadows (Murray \& Wetzel 1987). NPP of the unvegetated areas appeared to be higher relative to the vegetated areas during the more productive times of year. This may indicate that a larger portion of what is produced in these areas is directly available to the water column. Benthic microalgae are assimilated with relatively high efficiencies by herbivorous grazers and could be an important source of carbon for higher trophic levels (Zimmerman et al. 1979, Morgan 1980). The annual.

Table 4. Annual estımates (mol $\mathrm{Cm}^{-2} \mathrm{yr}^{-1} ; \pm 1$ standard devjation) of gross primary production (GPP), respiration (R), and net primary production (NPP) (all in mol $\mathrm{C} \mathrm{m}^{-2} \mathrm{Yr}^{-1}$ ), predicted from continuous PAR and water temperature data

\begin{tabular}{lrrr|}
\hline & GPP & R & \multicolumn{1}{c|}{ NPP } \\
\hline Community & $59.2 \pm 1.8$ & $51.4 \pm 1.5$ & $7.8 \pm 0.0$ \\
Benthos & $57.0 \pm 0.9$ & $43.2 \pm 0.6$ & $13.8 \pm 0.0$ \\
Water column & $2.2 \pm 0.9^{\circ}$ & $8.2 \pm 0.9$ & $-6.0 \pm 0.4$ \\
& & \\
a Ziegler \& Benner (1998) & & \\
'An annually weighted estimate derived from daily mea- \\
surements made throughout the year, each applied to the \\
month the measurement was made as well as the previ- \\
ous or following month, and summed over the year to \\
obtain an annual estimate
\end{tabular}

estimate of the GPP of the unvegetated areas $(17.7 \mathrm{~mol}$ $\mathrm{C} \mathrm{m}^{-2} \mathrm{yr}^{-1}$ ) represents about $7.5 \%$ of total community GPP (Table 4), assuming an areal coverage of $25 \%$, which is consistent with the contribution of microalgae reported for other seagrass ecosystems (Thayer et al. 1975, Murray \& Wetzel 1987). Benthic microalgae, therefore, provide a direct and efficient link to higher trophic levels in Laguna Madre and may represent an important alternative pathway to the less efficient detritus-based food web typically depicted in seagrass systems (Robertson et al. 1982, Chin-Leo \& Benner 1991, Peduzzi \& Herndl 1991).

\section{Coupling between the benthos and water column}

The concept of benthic-pelagic coupling is normally applied to deeper aquatic systems where the heterotrophic activity of the aphotic benthos is supported by phytoplankton production occurring in the euphotic zone (Graf 1989, 1992). Hargrave (1973) determined that oxygen consumption in the benthos was an indicator of primary production in the mixed-layer depth for several bays, lakes, sounds, and offshore locations. Our data from Laguna Madre suggest a very different. relationship between the benthos and overlying water column. The water column was strongly net heterotrophic during most of the year. Water column respiration was greatest when benthic NPP was highest due to exudation of DOM from seagrasses and algae. This was clearly demonstrated by the significant positive correlation between oxygen consumption measured in the water column and the daily benthic NPP $\left(\mathrm{r}^{2}=0.88\right.$, $p<0.002, n=7$, Fig. 5). This regression analysis indicated that about $88 \%$ of the variability in water column $\mathrm{R}$ could be explained by benthic NPP. In contrast, the regression analysis for water temperature versus $R$ was not significant $\left(\mathrm{r}^{2}=0.33, \mathrm{p}=0.11, \mathrm{n}=10\right)$, indicating

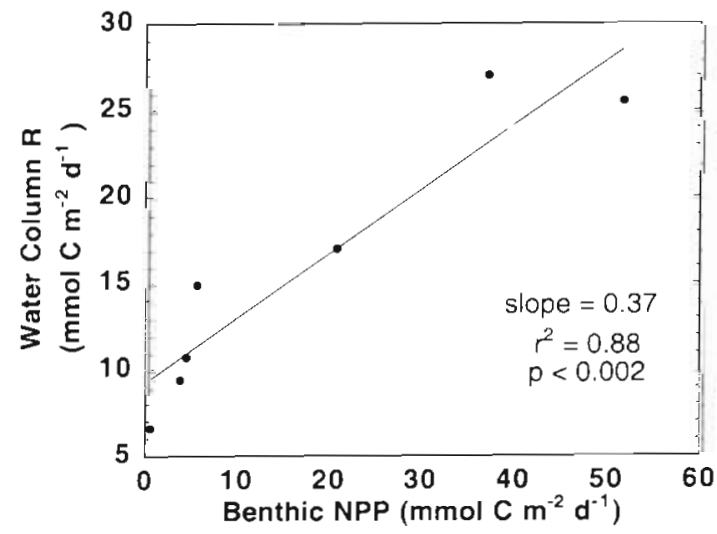

Fig. 5. Water column respiration. (R) versus the corresponding benthic net primary production (NPP) 
that temperature had a minimal influence on $\mathrm{R}$ in the water column.

The trophic status of the water column and its link to benthic processes in seagrass ecosystems may depend on freshwater inflow. Increased terrestrial runoff during the wet season coincided with increased phytoplankton production in a Ruppia maritima dominated, tropical lagoon (Flores-Verdugo et al. 1988). A comparison of lagoonal systems with permanently open inlets (like the lower Laguna Madre) versus those with restricted inlets indicated that water column primary production was about 10 times greater in the systems with restricted inlets. This phenomenon was attributed to the high nutrient loading during the wet season and the retention of nutrients and plankton biomass during the dry season in systems with restricted inlets (FloresVerdugo et al. 1988). Water column GPP measured in the lower Laguna Madre was similar to the lowest values reported for lagoons with continuously open inlets and minimal freshwater input, as cited in FloresVerdugo et al. (1988). The lack of allochthonous input is probably a major reason for the tight coupling between the water column and benthos of the lower Laguna Madre.

\section{Seasonal patterns in the sources and utilization of DOM}

Benthic NPP represents a measure of how much carbon fixed in the benthos is potentially available to the water column. Benthic NPP was highest in summer and lowest in the fall, and it was generally found to equal or exceed carbon demand in the water column. However, in the late summer and fall, water column R appeared to have exceeded benthic NPP, suggesting that $R$ may have been supported by the release of DOM from leaching and decomposition of senescent seagrass material which is abundant at this time of year. It has been suggested that low rates of seagrass decomposition can sustain the benthos during periods of low primary productivity (Harrison \& Mann 1975). Seasonal variations in benthic NPP, as well as shifts in the processes responsible for the release of DOM, appeared to regulate heterotrophic activity in the water column.

The utilization of DOC in the water column was rapid during the summer months as indicated by mean DOC residence times of 7 to $11 \mathrm{~d}$. The water column demand for DOC in July was similar to the benthic release of DOC (Fig. 6a), indicating that it is rapidly utilized and therefore quite labile. In September, demand for DOC in the water column was much lower than in July, although water temperature was the same as in July (Fig. 6b). The benthic flux of DOC in Sep- (a)

(b)

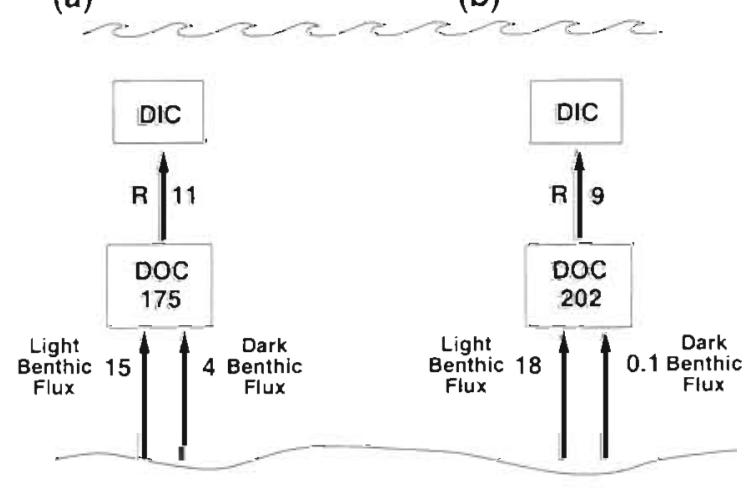

July 25, 1996

September 12, 1996

(c)

(d)

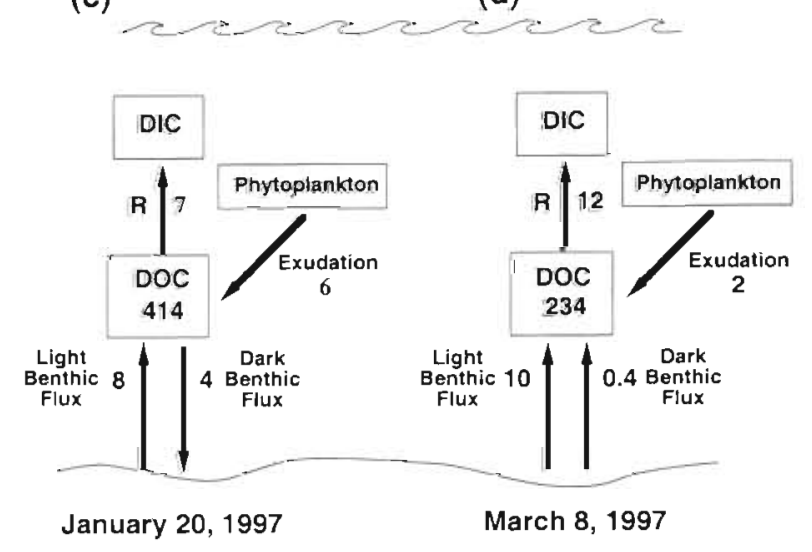

Fig. 6. Illustrations of the benthic fluxes of dissolved organic carbon (DOC), water column respiration (R), and estimated phytoplankton DOC exudation (calculated as $10 \%$ of gross primary production) for (a) July 25, 1996, (b) September 12, 1996, (c) January 20, 1997, and (d) March 8, 1997. All rates are

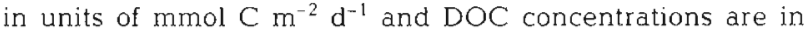
$\mathrm{mmol} \mathrm{C} \mathrm{m} \mathrm{m}^{-2}$

tember was much larger than benthic NPP, and may have indicated that processes not directly related to photosynthesis such as leaching, decomposition, and release of porewater DOC were important. However, no significant fluxes of DOC from the benthos were measured in the dark at this time. Thus the relatively high benthic $\mathrm{R}$ in September may have been maintained by carbon stored as porewater DOC or seagrass and algal detritus that accumulated throughout the summer

In November there was net benthic consumption of DOC, and water column $\mathrm{R}$ was lowest, possibly reflecting substrate limitation. The mean residence time for DOC in November (18 d) was longer than during the summer and could have been due to decreases in temperature as well as low substrate availability. In January, with the occurrence of a brown tide, phytoplankton were a major source of carbon in the water column. 
The utilization of DOC in the water column was slightly below the estimates of benthic and water column DOC production (Fig. 6c), assuming 10\% of phytoplankton GPP was released as DOC through exudation and grazing (Lancelot 1984, Williams 1990, Strom et al. 1997). Although phytoplankton significantly contributed to the DOC pool, water temperatures $\left(10\right.$ to $\left.12^{\circ} \mathrm{C}\right)$ probably limited the utilization of DOC during the winter (mean residence time of $30 \mathrm{~d}$ for DOC in January)

Phytoplankton production was less important in March, and the benthic DOC flux was larger than in January (Fig. 6d). Benthic NPP was high at this time, indicating an abundant supply of benthic production was potentially available to support $\mathrm{R}$. The increased water column $\mathrm{R}$ and high bacterial growth efficiency ( $38 \%$ ) in March probably resulted from the utilization of labile DOM from benthic production. The decrease in mean residence time for DOC in March (19 d) relative to January ( $30 \mathrm{~d}$ ) was probably a result of both the presence of some phytoplankton-derived DOC from the winter bloom and the sharp increase in water temperature (average $21^{\circ} \mathrm{C}$ ). In June 1997, an increase in both water temperature and the release of DOC from the benthos was accompanied by its rapid utilization in the water column (mean residence time of $8 \mathrm{~d}$ ). During the spring and summer, the close balance between DOC released from the benthos and microbial utilization in the water column indicates that the material released, probably seagrass exudate, represents a very labile component of the DOM.

\section{Significance of seagrass-derived DOM}

There are 3 main processes potentially responsible for the release of DOC from the benthos in Laguna Madre: (1) exudation by seagrass and algae, (2) leaching and decomposition of seagrass and algal material, and (3) the release of DOC from sediment pore-waters. It was not possible to directly quantify the contribution of each process, but there is strong indirect evidence from this study that indicates exudation by seagrasses is substantial and represents an important source of DOM. Diurnal variations in bacterial production have been measured in the water column over seagrass beds in previous studies conducted in the upper Laguna Madre as well as in Moreton Bay, Australia, and maximal rates of bacterial production were found in early to mid-afternoon (Moriarty \& Pollard 1982, Chin-Leo \& Benner 1991). The authors hypothesized that this diurnal variation was caused by lightmediated processes such as seagrass exudation.

A diurnal change in bacterioplankton production was measured in the lower Laguna Madre on June 25, 1997. However, this increase in bacterioplankton production in the afternoon was not found on the previous day (June 24) when light levels were much lower (59\% lower) due to thick cloud cover (Table 5). Benthic NPP and DOC fluxes measured in the light on June 24, 1997, were dramatically lower than those measured on June 25, 1997, when light levels were much higher (Table 5). These 2 very different light environments on consecutive days provided a clear demonstration of the link between benthic primary production, the release of DOC, and its utilization by bacterioplankton (Table 5). Throughout the year the release of DOC from the benthos primarily occurred in the light, almost exclusively in seagrass-dominated sediments, and was directly related to benthic NPP. Collectively, these field measurements indicated that much of the DOM released from the benthos was due to seagrass exudation

Exudation of DOC by seagrasses has generally been considered to be minor. Laboratory studies, using ${ }^{14} \mathrm{C}$ labeled seagrasses in short-term incubations, have indicated that exudation was less than $5 \%$ of carbon fixed (Brylinsky 1977, Penhale \& Smith 1977, Wetzel \& Penhale 1979). These values are considered minimal estimates due to the assumption of isotopic equilibrium during brief incubation periods. In the present study, seagrass exudation was estimated to be $1.4 \mathrm{~mol} \mathrm{C} \mathrm{m}^{-2}$ $\mathrm{yr}^{-1}$, assuming exudation represents about $10 \%$ of benthic NPP (Fig. 4), Leaching of senescent seagrass tissues is another potentially important source of DOC in seagrass systems (Kirkman \& Reid 1979). DOC released via leaching in the lower Laguna Madre was 
estimated to be $1.7 \mathrm{~mol} \mathrm{C} \mathrm{m}^{-2} \mathrm{yr}^{-1}$ based on average seagrass biomass (113 $\mathrm{g} \mathrm{dw} \mathrm{m} \mathrm{m}^{-2}$; Kaldy 1997), weight percent $C$ of the leaf tissues (35.2\%; Kaldy 1997), and leaf turnover time (1 $\mathrm{yr}^{-1}$; Kaldy 1997), and assuming $50 \%$ of seagrass biomass is lost through leaching (Opsahl \& Benner 1993). These rough estimates indicate that the magnitude of seagrass exudation and leaching were similar, and therefore may be of equal importance to the release of DOM. However, the temporal significance of these processes probably varies seasonally, with exudation being more significant in the spring and summer and leaching more significant in the fall and winter.

The linear relationship between benthic NPP and net DOC flux measured in the light indicated that the release of DOC due to seagrass exudation occurred throughout the year. It is important to note that annual benthic NPP, which represents the total carbon potentially available to the water column $\left(14 \mathrm{mmol} \mathrm{C} \mathrm{m} \mathrm{m}^{-2}\right.$ $\mathrm{yr}^{-1}$ ), was very similar to the annual carbon demand based on $\mathrm{R}$ in the water column $\left(8 \mathrm{mmol} \mathrm{C} \mathrm{m}^{-2} \mathrm{yr}^{-1}\right)$ (Table 4). Annual estimates indicated that water column $\mathrm{R}$ would require about $59 \%$ of the benthic NPP and about $14 \%$ of community GPP. These results suggest that bacterioplankton in seagrass ecosystems require a much greater fraction of benthic production then previously believed, and a major fraction of the carbon fueling water column respiration is derived from seagrass exudation.

Acknowledgements. The authors especially thank Beau Hardegree for extensive and essential field and laboratory assistance. We also appreciate the assistance of Don Hockaday at the UT-PanAm Coastal Studies Laboratory, South Padre Island, Texas, who provided needed laboratory space and facilities during field trips to the lower Laguna Madre. We also thank Ken Dunton, Jim Kaldy, and Joe Kowalski for providing continuous PAR irradiance data. This research was supported by NSF grant DEBB 9420652 . This is contribution number 1087 from the University of Texas Marine Science Institute.

\section{LITERATURE CITED}

Amon RWM, Benner R (1998) Seasonal patterns of bacterial abundance and production in the Mississippi River plume and their importance for the fate of enhanced primary production. Microb Ecol 35:289-300

Behrens EW (1966) Surface salinities for Baffin Bay and Laguna Madre, Texas, April 1964 - March 1966. Publ Inst Mar Sci 11:168-173

Benner R, Strom M (1993) A critical evaluation of the analytical blank associated with DOC measurements by hightemperature catalytic oxidation. Mar Chem 41:153-160

Benner R, Peele E، Hodson RE (1986) Microbial utilization of dissolved organic matter from leaves of the red mangrove, Rhizophora mangle, in the Fresh Creek estuary, Bahamas. Estuar Coast Shelf Sci 23:607-619
Biddanda B, Opsahl S, Benner R (1994) Plankton respiration and carbon flux through bacterioplankton on the Louisiana shelf. Limnol Oceanogr 39(6):1259-1275

Brylinsky M (1977) Release of dissolved organic matter by some marine macrophytes. Mar Biol 39:213-220

Chin-Leo G, Benner R (1991) Dynamics of bacterioplankton abundance and production in seagrass communities of a hypersaline lagoon. Mar Ecol Prog Ser 73:219-230

Chin-Leo G, Benner R (1992) Enhanced bacterioplankton production and respiration at intermediate salinities in the Mississippi River plume. Mar Ecol Prog Ser 87:87-103

Critchfield $H$ (1974) General climatology, 3rd edn. Prentice Hall, Englewood Cliffs, NJ, p 446

del Giorgio PA, Cole JJ, Cimbleris A (1997) Respiration rates in bacteria exceed phytoplankton in unproductive aquatic systems. Nature 385:148-151

den Hartog C (1977) Structure, function, and classification in seagrass communities. In: McRoy CP, Helfferich C (eds) Seagrass ecosystems. A scientific perspective. Dekker, New York, p 89-121

Dunton KH, Tomasko DA (1994) In situ photosynthesis in the seagrass Halodule wrightii in a hypersaline subtropical lagoon. Mar Ecol Prog Ser 107:281-293

Findlay S, Carlough L, Crocker MT, Gill HK, Meyer JL, Smith PJ (1986) Bacterial growth on macrophyte leachate and fate of bacterial production. Limnol Oceanogr 31(6): $1335-1341$

Flores-Verdugo FJ, Day JW, Mee L, Briseno-Duenas R (1988) Phytoplankton production and seasonal biomass variation of seagrass, Ruppia maritima L., in a tropical Mexican lagoon with an ephemeral inlet. Estuaries 11(1):51-56

Fry B, Parker PL (1979) Animal diet in Texas seagrass meadows: $\delta^{13} \mathrm{C}$ evidence for the importance of benthic plants. Estuar Coast Mar Sci 8:499-509

Graf G (1989) Benthic-pelagic coupling in a deep-sea benthic community. Nature 341:437-439

Graf G (1992) Benthic-pelagic coupling: a benthic view. Oceanogr Mar Biol Annu Rev 30:149-190

Hargrave BT (1973) Coupling carbon flow through some pelagic and benthic communities. J Fish Res Board Can 30(9):1317-1326

Harrison PG, Mann KH (1975) Detritus formation from eelgrass (Zostera marina L.): the relative effects of fragmentation, leaching, and decay. Limnol Oceanogr 20(6): 924-934

Hedgpeth JW (1967) Ecological aspects of the Laguna Madre, a hypersaline estuary. In: Lauff GH (ed) Estuaries. American Association for the Advancement of Science, Washington, DC, p 408-420

Herzka SZ, Dunton KH (1996) Seasonal photosynthetic patterns of the seagrass Thalassia testudium in the western Gulf of Mexico. Mar Ecol Prog Ser 152:103-117

Hough RA, Wetzel RG (1975) The release of dissolved organic carbon from submersed aquatic macrophytes: diel, seasonal and community relationships. Ver Int Ver Theor Angew Limnol 19:939-948

Humm H.J, Hildebrand HH (1962) Marine algae from the gulf Coast of Texas and Mexico. Publ Inst Mar Sci 8: $227-268$

Kaldy JE (1997) Production dynamics, reproductive ecology and demography of Thalassia testudinum (turlle grass) from the Lower Laguna Madre, Texas. Phd dissertation, University of Texas at Austin

Kirchman DL, Mazzella L, Alberte RS, Mitchell R (1984) Epiphytic bacterial production on Zostera marina. Mar Ecol Prog Ser 15:117-123

Kirchman DL, K'nees E, Hodson RE (1985) Leucine incorpora- 
tion and its potential as a measure of protein synthesis by bacteria in natural aquatic systems. Appl Environ Microbiol 49:599-607

Kirkman H, Reid DD (1979) A study of the role of the seagrass Posidonia australis in the carbon budget of an estuary. Aquat Bot 7:173-183

Lancelot C (1984) Extracellular release of small and large molecules by phytoplankton in the Southern Bight of the North Sea. Estuar Coast Shelf Sci 18:65-77

Lee S, Fuhrman JA (1987) Relationships between biovolume and biomass of naturally derived marine bacterioplankton. Appl Environ Nicrobiol 53:1298-1303

Lindeboom HJ, De Bree BHHD (1982) Daily production and consumption in an eelgrass (Zostera Marina) Community in saline lake Grevelingen: discrepancies between the $\mathrm{O}_{2}$ and ${ }^{14} \mathrm{C}$ Method. Neth J Sea Res 16:362-379

Mann KH (1988) Production and use of detritus in various freshwater, estuarine, and coastal marine ecosystems. Limnol Oceanogr 33(4):910-930

McRoy CP, Helfferich C (1974) Seagrass ecosystems: a scientific perspective. Marcel Dekker, Inc, New York, p 314

McRoy CP, McMillan C (1977) Production ecology and physiology of seagrasses. In: McRoy CP, Helfferich C (eds) Seagrass ecosystems. A scientific perspective. Dekker, New York, p 53-87

Moncreiff CA, Sullivan MJ, Daehnick AE (1992) Primary production dynamics in seagrass beds of Mississippi Soundthe contribution of seagrass, epiphytic algae, sand microflora, and phytoplankton. Mar. Ecol Prog Ser 87(1-2): 161-171

Morgan MD (1980) Grazing and predation of the grass shrimp Palaemonetes pugio. Limnol Oceanogr 25(5): 896-902

Moriarty DJW, Pollard PC (1982) Diel variation of bacterial productivity in seagrass (Zostera capricorni) beds measured by rate of thymidine incorporation into DNA. Mar Biol 72:165-173

Moriarty DJW, Roberts DG, Pollard PC (1.990) Primary and bacterial productivity of tropical seagrass communities in the Gulf of Carpentaria, Australia. Mar Ecol Prog Ser 61:145-157

Murray L, Wetzel RL (1987) Oxygen production and consumption associated with the major autotrophic components in two temperate seagrass communities. Mar Ecol Prog Ser 38:231-239

NOAA (1990) Estuaries of the United States: vital statistics of a national resource base, edn. Strategic Environmental Assessments Division, Rockville, MD

Odum EP (1971) Fundamentals of ecology. WB Saunders Company, Philadelphia, p 574

Odum HT, Hoskin CM (1958) Comparative studies on the metabolism of marine waters. Publ Inst Mor Sci Unıv Texas 5:16-46

Odum HT, Wilson RF (1962) Further studies on reaeration and metabolism of Texas Bays, 1958-1960. Publ Inst Mar Sci Univ Texas 8:23-55

Odum HT, Burkholder PR, Rivero J (1959) Measurements of productivity of turtle grass flats, reefs, and the Bahia Fosforescente of southern Puerto Rico. Publ Inst Mar Sci Univ Texas 6:159-170

Onuf CP (1996) Biomass patterns in seagrass meadows of the Laguna Madre. Texas Bull Mar Sci 58(2):404-420

Opsahl S, Benner R (1993) Decomposition of senescent blades

Editorial responsibility: Otto Kinne (Editor),

Oldendorf/Luhe, Germany of the segrass Halodule wrightii in a subtropical lagoon. Mar Ecol Prog Ser 94:191-205

Oviatt CA, Rudnick DT, Keller AA, Sampou PA, A.lmquist GT (1986) A comparison of system $\left(\mathrm{O}_{2}\right.$ and $\left.\mathrm{CO}_{2}\right)$ and $\mathrm{C}-14$ measurements of metabolism in estuarine mesocosms. Mar Ecol Prog Ser 28:57-67

Peduzzi P. Herndl GJ (1991) Decomposition and significance of seagrass leaf litter (Cymodocea nodosa) for the microbial food web in coastal waters (Gulf of Trieste, Northern Adriatic Sea). Mar Ecol Prog Ser 71:163-1.74

Penhale PA, Smith WO (1977) Excretion of dissolved organic carbon carbon by eelgrass (Zostera marina) and its epiphytes. Limnol Oceanogr 22(3):400-407

Penhale PA, Thayer GW (1980) Uptake and transfer of carbon and phosphorus by eelgrass (Zostera marina L.) and its epiphytes. J Exp Mar Biol Ecol 42:113-123

Pollard PC, Moriarty DJW (1991) Organic carbon decomposition, primary and bacterial productivity, and sulfate reduction, in tropical seagrass beds of the Gulf of Carpentaria, Australia. Mar Ecol. Prog Ser 69:149-159

Pomeroy LR (1959) Algal productivity in salt marshes of Georgia. Limnol Oceanogr 4:386-397

Porter KG, Feig YS (1980) The use of DAPl for identifying and counting aquatic microflora. Limnol Oceanogr 25:943-948

Quammen ML, Onuf CP (1993) Laguna Madre: seagrass changes continue decades after salinity reduction. Estuaries 1.6(2):302-310

Robertson ML, Mills AL, Zieman JC (1982) Microbial synthesis of detritus-like particulates from dissolved organic carbon released by tropical seagrasses. Mar Ecol Prog Ser 7: 279-285

Strom SL, Benner R, Ziegler S, Dagg MJ (1997) Planktonic grazers are a potentially important source of marine dissolved organic carbon. Limnol Oceanogr 42(6): $1364-1374$

TDWR (1983) Laguna Madre Estuary: a study of the influence of freshwater inflows, edn. Water Development Board and Texas Water Commission, Austin, TX

Tenore KR (1977) Growth of the polychaete, Capitella capitata, cultured on different levels of detritus derived from various sources. Limnol Oceanogr 22:936-941

Thayer GW, Adams SM, Croix MWL (1975) Structural and functional aspects of a recently established Zostera marina community. In: Cronin LE (ed) Estuarine research. Academic Press, New York, p 518-546

Trewartha G (1961) Earth's problem climates. University of Wisconsin Press, Madison

Wetzel RG, Penhale PA (1979) Transport of carbon and excretion of dissolved organic carbon by leaves and roots/ rhizomes in seagrasses and their epiphytes. Aquat Bot 6: $149-158$

Williams PJL (1981) Incorporation of microheterotrophic processes into the classical paradigm of the planktonic food web. Kiel Meeresforsch 5:1-28

Williams PJL (1990) The importance of losses during microbial growth; commentary on the physiology, measurement and ecology of the release of dissolved organic material. Mar Microb Food Webs 4:175-206

Ziegler S, Benner R (1998) Ecosystem metabolism in a subtropical seagrass-dominated lagoon. Mar Ecol Prog Ser $173: 1-12$

Zimmerman R, Gibson R, Harrington J (1979) Herbivory and detritivory among gammaridean amphipods from a Florida seagrass community. Mar Biol 54:41-47

Submitted: May 20, 1998; Accepted: December 2, 1998

Proots received from author(s): April 13, 1999 